for some time before they start treatment with maintenance haemodialysis are more liable to have renal osteodystrophy and peripheral neuropathy. After dialysis is begun their anaemia remains more severe, they gain weight more slowly, and wound healing is often markedly impaired. In some of these patients full recovery may take up to one year.

It appears reasonable therefore to increase protein intake to a level where nitrogen balance is achieved. An increase in protein intake from around 0.3 to $0.5 \mathrm{~g} . / \mathrm{kg}$./day is usually associated with only a small rise in blood urea. It would seem that when other forms of treatment for terminal renal failure are available reduced protein diets should be used only for short periods, and that the intake of protein should be $0.5 \mathrm{~g}$./ $\mathrm{kg}$./day ( $35 \mathrm{~g}$. for a $70-\mathrm{kg}$. man) to keep the patient in nitrogen balance.

We are grateful for the assistance of the nursing staff of the metabolic unit, Fulham Hospital, and to Mrs. J. Cheston, Miss P. Matthews, Miss B. C. Atkins, and Miss C. Durrant for technical help.

This work was supported by a grant from the Charing Cross Hospital Subcommittee for Clinical Research and in part by Grant No. AM-05008 of the National Institutes of Health, Department of Health, Education and Welfare, Public Health Service of the U.S.A. Slow-Na tablets were supplied by Ciba.

\section{REFERENCES}

Allison, J. B. (1951). Fed. Proc., 10, 676.

Allison, J. B. (1957). ₹. Amer. med. Ass., 164, 283.

Berlyne, G. M., and Hocken, A. G. (1968). In Proceedings of a Conference on Nutrition in Renal Disease, edited by G. M. Berlyne, p. 43. Livingstone, Edinburgh.
Bricker, M., Mitchell, H. H., and Kinsman, G. M. (1945). F. Nutr., 30, 269.

Clarkson, E. M., MaDonald, S. J., de Wardener, H. E., and Warren, R. (1965). Clin. Sci., 28, 107

Clarkson, E. M., McDonald, S. J., and de Wardener, H. E. (1966). Clin. Sci., 30, 425 .

Davidson, Sir S., and Passmore, R. (1966). Human Nutrition and Dietetics, 3rd ed. Livingstone, Edinburgh.

Forsyth, B. T., Shipman, M. E., and Plough, I. C. (1955). F. clin. Invest., 34, 1653 .

Giordano, C. (1963). ¥. Lab. clin. Med., 62, 231.

Giordano, C. (1963). F. Lab. clin. Medings of 2 nd International Congress of Nephrology, Prague, edited by J. Vostál and G. Richet, p. 752. Excerpta Medica Foundation, Amsterdam.

Giordano, C., Esposito, R., de Pascale, C., and de Santo, N. G. (1967). In Proceedings of 3rd International Congress of Nephrology, Washington, edited by E. L. Becker, vol. 3, p. 214. Karger, Basle.

Giovannetti, S., and Maggiore, Q. (1964). Lancet, 1, 1000.

Hegsted, D. M. (1964). In Mammalian Protein Metabolism, edited by H. N. Munro and J. B. Allison, vol. 2, p. 135. Academic Press, New Yark.

Herndon, R. F., Freeman, S., and Cleveland, A. S. (1958). F. Lab. clin. Med., 52, 235.

Kempner, W. (1945). N.C. med. 7., 6, 61, 117.

Kempner, W. (1945). N.C. med. 7., 6, 61, 117. Proc. roy. Soc. Med., 60, 115.

Kopple, J. D., Shinaberger, J. H., Coburn, J. W., and Rubini, M. E. (1968). American Society of Nephrology, Abstracts of 2nd Meeting, p. 33 .

Lancet, 1963, 1, 811 .

Reifenstein, E. C., jun., Albright, F., and Wells, S. L. (1945). F. clin. Endocr. 5, 367 .

Richards, P., Metcalfe-Gibson, A., Ward, E. E., Wrong, O., and Houghton, B. J. (1967). Lancet, 2, 845 .

Rose, W. C. (1957). Nutr. Abstr. Rev., 27, 631.

Shaw, A. B., Bazzard, F. J., Booth, E. M., Nilwarangkur, S., and Berlyne, G. M.' (1965). Quart. F. Med., 34, 237.

Snyderman, S. E., Holt, L. E., jun., Dancis J., Roitman, E., Boyer, A., and Balis, M. E. (1965). f. Nutr., 78, 57.

Voit, C. (1867). Z. Biol., 3, 1 .

Weichselbaum, T. E. (1946). Amer. F. clin. Path., 16, 40 (Technical Section).

Whitby, L. G., and Lang, D. (1960). 7. clin. Invest., 39, 854

Wolthuis, F. H. (1961). Acta med. scand., 171, Suppl. No. 373, p. 2.

\title{
Broken Heart : A Statistical Study of Increased Mortality among Widowers
}

\author{
C. MURRAY PARKES,* M.D., D.P.M: ; B. BENJAMIN, $\dagger$ PH.D., F.I.A. ; R. G. FITZGERALD, $\ddagger$ M.D.
}

\begin{abstract}
Cummary : A total of 4,486 widowers of 55 years of age and older have been followed up for nine years since the death of their wives in 1957 . Of these 213 died during the first six months of bereavement, $40 \%$ above the expected rate for married men of the same age. Thereafter the mortality rate fell gradually to that of married men and remained at about the same level.

The greatest increase in mortality during the first six months was found in the widowers dying from coronary thrombosis and other arteriosclerotic and degenerative heart disease. There was also evidence of a true increase in mortality from other diseases, though the numbers in individual categories were too small for statistical analysis.

In the first six months $22.5 \%$ of the deaths were from the same diagnostic group as the wife's death. Some evidence suggests that this may be a larger proportion than would be expected by chance association, but there is no evidence suggesting that the proportion is any different among widows and widowers who have been bereaved for more than six months.
\end{abstract}

\section{Introduction}

To most of us death from a "broken heart" is a figure of speech, yet the term reflects a bygone belief that grief could kill, and kill through the heart.
In 1963 a report was published of a follow-up of a cohort of all men of 55 years and older who were widowed in England and Wales during January and July of 1957 (Young, Benjamin, and Wallis, 1963). This showed that during the first six months of bereavement the mortality rate was $40 \%$ greater than the mortality rate for married men of the same age, and that this increase gradually fell thereafter to the level of the rate for married men.

More recently Rees and Lutkins (1967) reported the results of a survey of the death rate among 903 relatives of patients dying in a semirural area of Wales. They found that $4.8 \%$ of bereaved close relatives died within a year of bereavement compared with $0.68 \%$ of a non-bereaved control group. The greatest increase was found among widows and widowers, their mortality rate being ten times greater than that of the matched controls. After the first year of bereavement mortality rates fell off sharply and were not significantly higher than in the control group.

The study by Cox and Ford (1964) of mortality rates among widows shows a rise during the second but not the first six months of bereavement. This study relies on the widow having

* Member Research Staff, Tavistock Institute of Human Relations,

London N.W.3.
t Director, Research and Intelligence Unit, Greater London Council,

$\neq \begin{aligned} & \text { London S.E.1. } \\ & \ddagger \text { Clinical Associate, National Institute of Mental Health, Bethesda, }\end{aligned}$ Maryland 20014, U.S.A. 
applied for a contributory pension, but, as the authors pointed out, many widows who become ill and die during the first six months after the death of their husbands may never have applied for a pension.

None of these studies has attempted to determine the particular diagnoses which contribute to the increased post-bereavement mortality rate, and none has followed up a cohort of bereaved persons for more than six years.

This paper reports a nine-year follow-up of the widowers studied by Young et al. (1963), with additional information, which was not previously reported, concerning certified causes of death and social class.

\section{Method}

A total of 4,486 widowers of 55 years of age and older were identified from the death certificates of their wives. The punch cards of the N.H.S. Central Register were then tagged so that the death of any of these men would automatically be reported. Information concerning age, occupation, and the certified cause of death was obtained from the death certificates of the widowers.

\section{Results}

Figures showing the overall mortality rate as a proportion of the mortality rate for married men of the same age during the first four years of bereavement have been published (Young et al., 1963). At that time the possibility of a further subsequent rise was discussed.

Fig. 1 shows the findings extended to include the first nine years of bereavement. It can be seen that the increment in mortality rate of $40 \%$ which occurred during the first six months of bereavement is subsequently followed by a gradual return to around the level for married men of the same age and that there is no subsequent rise in mortality.

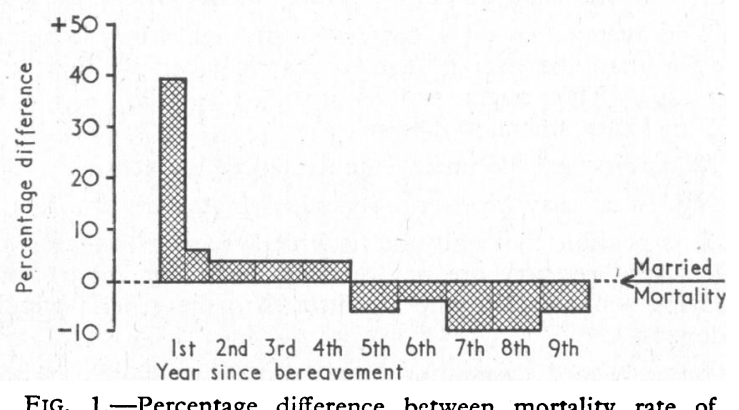

wid. 1.-Percentage difference between mortality rate of by years since bereavement. $\mathrm{N}=4,486$.

The number of deaths during the first six months is now found to be 213 as compared with 214 in the original paper, a false posting to the N.H.S. Central Register having been discovered.

\section{Cause of Death of Widowers}

Table I shows the causes of death among the 213 widowers who died within six months of their wives. These are compared with the number who would have been expected had these widowers had the same mortality rate as married men of the same age in England and Wales during 1957.

Fig. 2 shows the mortality rate among these widowers as a proportion of the expected rate. The greatest increase was in the group diagnosed as "coronary thrombosis and other arteriosclerotic and degenerative heart diseases." There were 77 deaths attributed to this cause, an increase of $67 \%$ above the expected number. The $99 \%$ confidence interval for the expected deaths from coronary thrombosis and other arteriosclerotic heart disease (together) is 25-67. The actual number of deaths is 77 , so that the excess is significant at the $1 \%$ level.

Table I.-Cause of Death Among the 213 Widowers Who Died Within Six Months of Their Wives Compared With the Number Expected from the Mortality Rate of Married Males of the Same Age in England and Wales During 1957

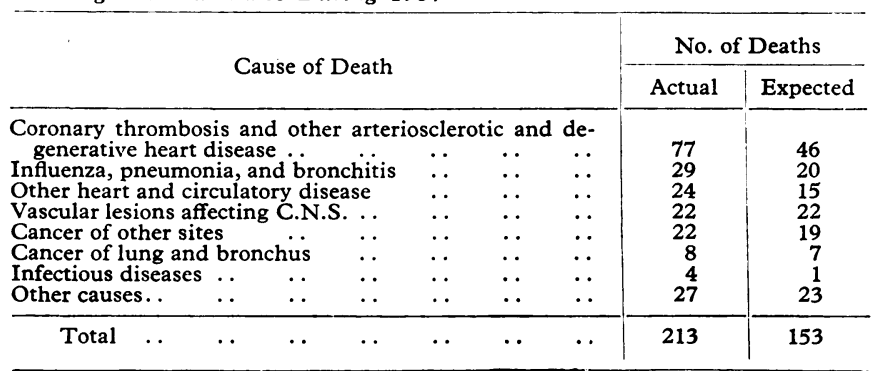

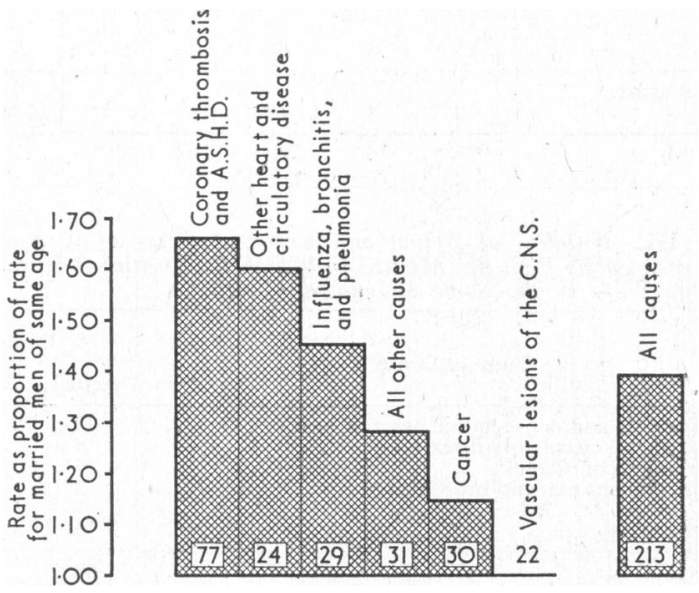

FIG. 2.-Mortality rate of widowers during first six months of bereavement as a proportion of rate for married men of the same age, by cause of death. Figures=number of deaths among 4,486 widowers.

The second greatest increase was found in the group diagnosed "other heart and circulatory disease." There were 24 deaths in this group, an increase of $60 \%$ over the expected number. Taken together diseases of the heart and circulatory systems accounted for two-thirds of the increase in mortality during the first six months of bereavement.

No disease group other than " coronary thrombosis and other anteriosclerotic and degenerative heart diseases" showed a statistically significant increase, but when all other causes of death were combined the $99 \%$ confidence interval for expected deaths is $77-137$ and the actual deaths number 136 . The excess is therefore only just short of significance at the $1 \%$ level.

\section{Cause of Death of Wife}

In Table II the cause of the death of the wives whose husbands died in the first six months is tabulated against the cause of death of their widowers. It will be seen that $48(22.5 \%)$ of them were diagnosed as dying from the same disease group as their spouses.

Assuming the null hypothesis that this represents a chance association, we would expect the proportional distribution of the deaths in each column of Table II to be the same as the distribution in the "total " column on the right-hand side. On this assumption it is easy to calculate the number of cases in each square of the matrix that we would expect to find by chance alone.

Table III shows the number of actual and expected cases in which the death of husband and wife were attributed to the same diagnostic group-38.7 cases were expected to coincide and $48(23.9 \%$ more $)$ actually did. 
TABLE II.-Actual Number of Cases of Widowers Bereaved in the First Six Months in Which the Cause of Death is the Same as for Their Wives. The Number Expected is Given in Parentheses

\begin{tabular}{|c|c|c|c|c|c|c|c|}
\hline \multirow[b]{2}{*}{$\begin{array}{l}\text { Cause Group of } \\
\text { Wife's Death }\end{array}$} & \multicolumn{6}{|c|}{ Cause Group of Widower's Death } & \multirow[b]{2}{*}{ ت્ّ } \\
\hline & 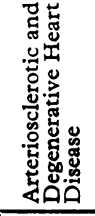 & 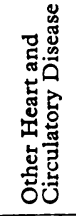 & 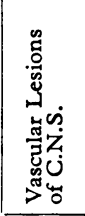 & 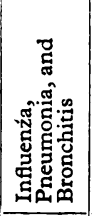 & 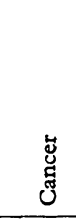 & 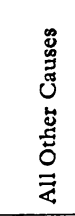 & \\
\hline $\begin{array}{l}\text { Arteriosclerotic and de- } \\
\text { generative heart disease }\end{array}$ & $\begin{array}{c}22 \\
(18 \cdot 79)\end{array}$ & 5 & 5 & 5 & 7 & 8 & 52 \\
\hline $\begin{array}{l}\text { Other heart and circula- } \\
\text { tory disease }\end{array}$ & 10 & $\begin{array}{c}5 \\
(2 \cdot 81)\end{array}$ & 2 & 4 & 2 & 2 & 25 \\
\hline $\begin{array}{l}\text { Vascular lesions of } \\
\text { C.N.S. }\end{array}$ & 19 & 6 & $\begin{array}{c}5 \\
(5 \cdot 68)\end{array}$ & 10 & 9 & 6 & 55 \\
\hline $\begin{array}{l}\text { Influenza, pneumonia } \\
\text { and bronchitis }\end{array}$ & 5 & 0 & 3 & $\begin{array}{c}3 \\
(2 \cdot 04)\end{array}$ & 1 & 3 & 15 \\
\hline Cancer & 13 & 5 & 6 & 4 & $\begin{array}{c}7 \\
(5 \cdot 77)\end{array}$ & 6 & 41 \\
\hline All other causes & 8 & 3 & 1 & 3 & 4 & $(3.64)$ & 25 \\
\hline Totals & 77 & 24 & 22 & 29 & 30 & 31 & 213 \\
\hline
\end{tabular}

TABLE III.-Number of Actual and Expected Cases of Widowers Bereaved in the First Six Months in Which the Deaths of Husband and Wife Were in the Same Diagnostic Group

\begin{tabular}{|c|c|c|c|c|c|c|c|c|}
\hline \multirow{2}{*}{\multicolumn{7}{|c|}{ Cause of Death }} & \multicolumn{2}{|c|}{ Deaths } \\
\hline & & & & & & & \multirow{2}{*}{$\begin{array}{c}\text { Actual } \\
22 \\
5 \\
5 \\
3 \\
7 \\
6 \\
\end{array}$} & \multirow{2}{*}{$\begin{array}{c}\text { Expected } \\
18.79 \\
2.81 \\
5.68 \\
2.04 \\
5.77 \\
3.64 \\
\end{array}$} \\
\hline \multicolumn{4}{|c|}{$\begin{array}{l}\text { Arteriosclerotic and degenerative heart } \\
\text { Other heart and circulatory disease } . . \\
\text { Vascular lesions of C.N.S. } \\
\text { Influenza, pneumo nia, and bronchitis }\end{array}$} & $\begin{array}{l}\text { sease } \\
\ldots \\
\cdots \\
\cdots \\
\cdots \\
\end{array}$ & $\begin{array}{l}. \\
\because \\
\cdots \\
\cdots \\
\end{array}$ & $\begin{array}{l}. \\
\because \\
\because \\
\therefore\end{array}$ & & \\
\hline Total & . & . & . & . & . & . & 48 & $38 \cdot 73$ \\
\hline
\end{tabular}

\section{Social Class}

The actual and expected deaths by social class-using the Registrar General's social class groupings by occupation (General Register Office, 1960)-is shown in Table IV. There is a suggestion of a gradient in the excess mortality with the highest excess in social class group I and the lowest in group V. The numbers in the extreme groups, however, are not large.

TABLE IV.-Mortality in the First Six Months of Bereavement for Widowers Over the Age of 55 by Social Class, Expressed as a Proportion of Mortality Rate for Married Men of the Same Age and portion of

\begin{tabular}{|c|c|c|c|c|}
\hline \multirow{2}{*}{\multicolumn{2}{|c|}{ Social Class }} & \multicolumn{2}{|c|}{ Deaths } & \multirow{2}{*}{$\frac{\text { Actual }}{\text { Expected }}$} \\
\hline & & Actual & Expected & \\
\hline 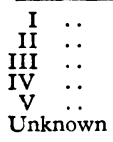 & $\begin{array}{l}\ldots \\
\cdots \\
\cdots \\
\cdots \\
\cdots\end{array}$ & $\begin{array}{r}4 \\
25 \\
107 \\
47 \\
19 \\
11\end{array}$ & $\begin{array}{r}2 \cdot 30 \\
17 \cdot 90 \\
69 \cdot 41 \\
34 \cdot 15 \\
15 \cdot 97 \\
13 \cdot 26\end{array}$ & $\begin{array}{l}1.74 \\
1.40 \\
1.54 \\
1.37 \\
1.19 \\
0.83\end{array}$ \\
\hline Total & $\ldots$ & 213 & 152.99 & 1.39 \\
\hline
\end{tabular}

In view of the association between social class and coronary heart disease which has been found in some studies these figures were further subdivided by diagnosis. The results are shown in Table V. It is apparent that the increase in six months' mortality from coronary and allied diseases in social class groups I-III is only $10 \%$ greater than that of social class groups IV and $\mathrm{V}$, whereas the increase in six months' mortality from other diseases is $16 \%$ greater in groups I-III than it is in groups IV and V. This differential, however, is not, having regard to the small numbers involved, statistically significant. It remains merely a suggestion that the excess mortality from coronary disease is less associated with social class than is the increased mortality from other diseases.
TABLE V.-Mortality in the First Six Months After Bereavement for Men Over the Age of 55 by Social Class and Diagnosis

\begin{tabular}{|c|c|c|c|c|c|c|c|c|c|c|}
\hline \multirow{2}{*}{\multicolumn{2}{|c|}{ Social Class }} & \multicolumn{3}{|c|}{$\begin{array}{l}\text { Coronary Throm- } \\
\text { bosis and Other } \\
\text { Arteriosclerotic } \\
\text { and Degenerative } \\
\text { Heart Diseases }\end{array}$} & \multicolumn{3}{|c|}{ All Other Causes } & \multicolumn{3}{|c|}{ All Causes } \\
\hline & & 营 & 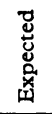 & 这 & 胥 & 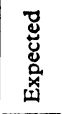 & $\stackrel{\leftrightarrow}{<}$ & 㤩 & 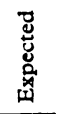 & 只 \\
\hline $\begin{array}{l}\text { I-III } \quad . . \\
\text { IV-V } \\
\text { Indeterminate }\end{array}$ & $\begin{array}{l}\ldots \\
\ldots\end{array}$ & $\begin{array}{r}50 \\
21 \\
5\end{array}$ & $\begin{array}{r}29 \\
13 \\
4\end{array}$ & $\begin{array}{l}1 \cdot 72 \\
1 \cdot 62 \\
1 \cdot 25\end{array}$ & $\begin{array}{r}85 \\
45 \\
6\end{array}$ & $\begin{array}{r}61 \\
37 \\
9\end{array}$ & $\begin{array}{l}1.38 \\
1.22 \\
1.67\end{array}$ & $\begin{array}{r}135 \\
66 \\
11\end{array}$ & $\begin{array}{l}90 \\
50 \\
13\end{array}$ & $\begin{array}{l}1.50 \\
1.32 \\
0.85\end{array}$ \\
\hline Total . . & $\ldots$ & $76^{*}$ & 46 & 1.65 & 136 & 107 & $1 \cdot 27$ & $212 *$ & 153 & $1 \cdot 38$ \\
\hline
\end{tabular}

\section{Discussion}

In the original paper by Young et al. (1963) the mortality was traced up to the end of the fifth year after bereavement, and it was noted that the mortality of widowers in the general population is in the region of 1.4 times that of married men of the same age. But it was shown that the increased mortality in this sample of 4,486 widowers is almost confined to the first six months of bereavement, after which it falls to that of married men of the same age. The possibility was mooted that a subsequent rise in mortality would take place which would bring the mortality rate of the sample into line with that of the general population of widowers.

Now that the sample has been followed up to the end of the ninth year it seems clear that no such rise is likely to take place ; in fact from the fifth year of bereavement the mortality rate is slightly below that of married men of the same age. Various possible explanations for this were discussed in the previous article, and we have no means of deciding between them. For the sake of completeness we list them here:

(1) The average age of widowers in any age group is about one year older than the average age of married men within the same age group. This might explain up to a quarter of the excess overall mortality among widowers.

(2) Widowers may be under-enumerated in the census.

(3) Widowers may be over-enumerated in the deaths.

(4) It is possible that only the healthier widowers remarry. Since widowers who remarry are not removed from our cohort we may be studying a population who are fitter than the general population of widowers.

(5) Some tagged cases may have been "lost"-that is to say, some of the widowers whose N.H.S. Central Register cards were tagged may not have been reported to the Registrar General's Office on their demise. This would result in a spuriously lower mortality rate in all years following bereavement.

Another matter which requires explanation is the difference between the $25 \%$ increase in mortality found in our study during the whole of the first year of bereavement and the tenfold increase (19 deaths in the bereaved group with only two deaths in the control group) in the study of widows and widowers in Llandidloes by Rees and Lutkins (1967). In fact the mortality rate among the widowers studied by us, $8.5 \%$, is not much different from the mortality rate of $12 \cdot 2 \%$ found by Rees and Lutkins among their widows and widowers. What is different is the low figure of $1.2 \%$ which they give as the mortality rate of their control group of married persons. This is probably lower than the mean rate for married persons of the same age in England and Wales (4.9\% in our study), and it seems must reflect some local peculiarity in the population studied.

Despite these differences it seems fair to conclude that there is a true increase in mortality among widowers during the first six months after bereavement. We must now consider the possible causes of this. 
The findings reported make it clear that the increased mortality is not explained by an increase in deaths from accident or infectious disease which might have been shared with the wife. In fact the greatest increase is found in the group diagnosed "coronary thrombosis and other arteriosclerotic and degenerative heart disease," which accounts for $53 \%$ of the increased mortality. In addition, there is some evidence of a true increase in mortality from other diseases, though the number in individual disease categories are too small for statistical analysis.

Death certificates are not necessarily a reliable source of information concerning cause of death. In a survey carried out by the General Register Office (1966) of 995 cases of death attributed by clinicians to coronary and arteriosclerotic heart disease there were 278 cases $(28 \%)$ in which the diagnosis was changed after post-mortem examination. A similar number of cases were changed from other diagnoses to coronary and arteriosclerotic heart disease by the pathologist, and misdiagnoses were attributed to many different diseases. While these observations throw some doubt on the reliability of our findings there is no reason to believe that the heart disease group is any more heavily weighted with incorrect diagnoses than other diagnostic groups.

If we accept that the increased mortality is largely attributable to coronary and arteriosclerotic heart disease we still have to explain this increase. Young et al. (1963) listed "homogamy" (the tendency of unfit to marry unfit) and "joint unfavourable environment" (the fact that husband and wife share a pathogenic environment) as possible explanations of the increased six-month mortality. If either of these were factors one would expect husband and wife to die from the same or similar diseases. In this study it has been shown that there is a tendency for this to occur. But if this were the main cause of the increased mortality following bereavement one would expect to find the greatest concordance in diagnosis in those diagnostic groups that account for the increased mortality rate. This is not the case, and in fact the number of husbands and wives who died from arteriosclerotic and other degenerative heart diseases was only three greater than expectation. Furthermore, the overall concordance rate in this study, which was $24 \%$ above chance expectation, is not much different from Ciocco's (1940) figures for married couples whose respective deaths were not limited to the first six months of bereavement. He found the concordance rate $18 \%$ above expectation.

These findings do not disprove the possible contribution which homogamy and joint unfavourable environment make to the increased mortality following bereavement, but they do make it less likely that these factors explain more than a part of the increased six-month mortality.

The finding that bereavement is associated with an increased mortality from coronary thrombosis does not necessarily mean that it is associated with an increase in the incidence of the disease. It may be that it simply increases the proportion of patients who died after having a coronary thrombosis. Even if the thrombosis itself does not occur until after bereavement it will presumably occur only if the coronary arteries are already diseased. In other words, bereavement may act as an aggravating or a precipitating factor in coronary thrombosis, but in either case it is unlikely to be the sole cause of death.

Psychological stress has long been thought to be a factor in this disease. For example, Weiss, Dlin, Rollin, Fischer, and Bepler (1957) found evidence of emotional stress in $86 \%$ of 43 coronary thrombosis cases compared with $9 \%$ of matched controls. But how such stresses influence the formation or course of the thrombosis remains a matter for conjecture. It is possible that emotional stress acts by altering the consumption of fats, sugar, coffee, or tobacco, ${ }^{1}$ all of which have been shown to be statistically related to the mortality from coronary artery disease

${ }^{1}$ Dell and Hill (1956) showed that the association between smoking and montality from coronary heart disease is almost confined to patients in this study. cally related to the mortality from coronary artery disease (Hammond and Horn, 1958 ; Paul et al., 1963 ; Yudkin, 1967). On the other hand, emotional stress alone has been shown to affect pulse rate, stroke volume, cardiac output, peripheral resistance, arterial blood pressure, exercise tolerance, and clotting-time, and to produce arrhythmias and electrocardiographic changes (Schneider and Zangari, 1951 ; Stevenson and Duncan, 1950). In patients with known hypertension, angina pectoris, or other structural heart disease such changes have been shown to have pathological effects (Hickham, Cargill, and Golden, 1948). All of which leads one to suspect that it may well be the emotional effects of bereavement, with the concomitant changes in psycho-endocrine functions, which are responsible for the increased mortality rate.

An association between social class and coronary thrombosis has been observed in Britain (Wilson and Heasman, 1959), though seldom in America (Epstein, 1965), but little is known of the effect of psychological stress within social class groups. In this study while the increase in mortality for all other diseases was $16 \%$ greater in social class groups I-III than it was in groups IV and V there was only a $10 \%$ difference in the effect of bereavement on mortality from coronary thrombosis and allied diseases between these classes. It seems that whatever the means by which bereavement is associated with heart disease it is one which cuts across social class differences.

If the findings of this study are typical we must conclude that nearly $5 \%$ of widowers over the age of 55 die within six months of the death of their wives, and that nearly a half of these deaths are from heart disease. Research is needed to discover whether widowers under 55 and widows are similarly at risk and to determine what intervention is possible to minimize this risk. Already much is known about the psychological and social consequences of bereavement, and if, as seems most likely, the baneful effects of bereavement on physical health are a response to psychological stress then anything which mitigates that stress can be expected to reduce the risk of its physical effects.

Programmes for the primary prevention of physical and mental illness by public and professional education and the provision of services to help people at times of crisis are in a stage of development (see, for instance, the outline of a primary prevention programme by Caplan, 1964), and it is an area which practising clinicians can ill afford to ignore.

Thanks are due to the staff of the Registrar General's Office for their assistance in the execution of the survey; to Dr. Michael Young and Dr. Christopher Wallis for permission to carry out this study of the cohort of widowers originally described by them ; and to Dr. C. J. Gavey and Dr. John Bowlby for their helpful criticism of the draft.

The work was supported by research grants from the Mental Health Research Fund, the Ministry of Health, and the National Institute of Mental Health, Washington D.C.

\section{REFERENCES}

Caplan, G. (1964). Principles of Preventive Psychiatry. Basic Books, New York.

Ciocco, A. (1940). Hum. Biol., 12, 508.

Cox, P. R., and Ford, J. R. (1964). Lancet, 1, 163

Doll, R., and Hill, A. B. (1956). Brit. med. f., 2, 1071.

Epstein, F. H. (1965). F. chron. Dis., 18, 735. General Register Office (1960). Classification of Occupations. London,
H.M.S.O.

General Register Office (1966). Studies on Medical and Population Subjects, No. 20 . London, H.M.S.O.

Hammond, E. C., and Horn, D. (1958). Ұ. Amer. med. Ass., 166, 1159 Hickham, J. B., Cargill, W. H., and Golden, A. (1948). f. clin. Invest., 27, 290.

Paul, O., et al. (1963). Circulation, 28, 20.

Paul, O., et al. (1963). Circulation, 28, 20.

Rees, W. D., and Lutkins, S. G. (1967). Brit. med. F., 4, 13.

Schneider, R. A., and Zangari, V. M. (1951). Psychosom. Med., 13, 289 Dis., 29,799. Duncan, C. H. (1950). Res. Publ. Ass. nerv. ment. Dis., 29, 799.

(1957). Arch. interm. Med. R., Fischer, H. K., and Bepler, C. R. Wilson, J. Arch. intern. Med., 99, 628. Lab. Serv., i8, 94 Young, M. Benjamin, B., and Wallis, C. (1963). Lancet, 2, 454.
Yudkin, J. (1967). New Scient. 